T. KolisnyK, D. LytKin, A. Zagayko, O. Ruban

National University of Pharmacy

\title{
Pharmacological eVAluation of SUSTAINed RELEASE MATRIX TABLETS CONTAINING VACCINIUM MYRTILLUS LEAF DRY EXTRACT AS AN ALPHA-GLUCOSIDASE INHIBITORY DRUG
}

Vaccinium myrtillus leaves are the source of natural polyphenols known to improve glycemic control in diabetic conditions through different mechanisms including intestinal a-glucosidase inhibition. In order to increase the effectiveness of $V$. myrtillus leaf dry extract as a-glucosidase inhibitory drug its sustained release matrix tablets have been developed.

Aim. To carry out the pharmacological evaluation of $V$. myrtillus leaf dry extract and its sustained release matrix tablets as a-glucosidase inhibitory agents.

Materials and methods. The matrix tablets were prepared by te wet granulation method. Experimental alimentary metabolic syndrome with persistent insulin resistance was induced in Syrian hamsters by feeding them with highly palatable fat- and sugar rich diet for 12 weeks. From the tenth week of the diet feeding, the pathological hamsters were treated with $V$. myrtillus leaf dry extract, its sustained release matrix tablets and voglibose tablets as a reference drug. At the end of the treatment period an oral maltose loading test with the determination of blood glucose and serum insulin concentration dynamics was performed. Vaccinium myrtillus leaf dry extract (VMLDE) was obtained according to the method developed under the supervision of Dr. O. Koshoviy (Department of Pharmacognosy, National University of Pharmacy, Kharkiv, Ukraine) [13]. The excipients used to manufacture sustained release matrix tablets were hypromellose (HPMC) of grades Methocel K4M and Methocel K100LV (Dow Chemical Company, USA), Eudragit L100 (Evonik, Germany), microcrystalline cellulose (MCC) of a grade Avicel PH101 (FMC BioPolymer, USA), Plasdone S-630 (Ashland Inc., USA) and magnesium stearate (S.D. Fine. Chemicals Ltd., India). The tablets containing 0.2 mg of voglibose ("Voksid" produced by Kusum Pharm LLC, Ukraine), a marketed $\alpha$-glucose inhibitor, were used as a reference drug in this study. Methods used : preparation of sustained release matrix tablets, induction of metabolic syndrome and experimental design, biochemical tests, statistical analysis.

Results and discussion. By all markers studied in this work the effectiveness of matrix tablets containing $V$. myrtillus leaf dry extract exceeded that one of the pure extract and statistically significantly did not differ from reference drug.

Conclusions. $V$. myrtillus leaf dry extract and its matrix tablets possess the antidiabetic action through several mechanisms, including, but not only intestinal a-glucosidase inhibition, therefore they can be considered as promising agents in diabetes and metabolic syndrome treatment.

Key words: Vaccinium myrtillus leaves; herbal extract; matrix tablets; diabetes mellitus; alpha-glucosidase inhibition; hamsters

\section{Т. Є. Колісник, Д. В. Литкін, А. Л. Загайко, О. А. Рубан}

Фармакологічна оцінка матричних таблеток тривалого вивільнення, що містять сухий екстракт листя чорниці, в якості інгібітора альфа-глюкозидаз

Листя чорниці звичайної $є$ джерелом природних поліфенолів, які покращують глікемічний контроль при діабетичних станах завдяки різним механізмам, включаючи інгібування кишкових $\alpha$-глюкозидаз. 3 метою підвищення ефективності сухого екстракту листя чорниці як засобу, що інгібує $\alpha$-глюкозидази, були розроблені його матричні таблетки тривалого вивільнення.

Метою даної роботи була фармакологічна оцінка сухого екстракту листя чорниці та його матричних таблеток тривалого вивільнення як засобів, що інгібують $\alpha$-глюкозидази.

Матеріали та методи. Матричні таблетки одержували методом вологої грануляції. Експериментальний аліментарний метаболічний синдром зі стійкою інсулінорезистентністю індукували у сирійських хом'яків з багатою на жири та вуглеводи (HPFS) дієтою впродовж 12 тижнів. 3 десятого тижня дієти хом'яки з модельною патологією отримували сухий екстракт листя чорниці, його матричні таблетки тривалого вивільнення і таблетки воглібози в якості референтного препарату. Наприкінці періоду лікування проводили пероральний тест мальтозного навантаження з визначенням динаміки концентрацій глюкози в крові та інсуліну в сироватці крові.

Результати та їх обговорення. За всіма дослідженими в даній роботі показниками ефективність матричних таблеток, що містять сухий екстракт листя чорниці, перевищувала ефективність чистого екстракту і статистично значимо не відрізнялася від референтного препарату.

Висновки. Сухий екстракт листя чорниці та його матричні таблетки чинять антидіабетичну дію через декілька механізмів, включаючи не тільки інгібування кишкових $\alpha$-глюкозидаз; отже, вони можуть розглядатися як перспективні засоби для лікування діабету та метаболічного синдрому.

Ключові слова: чорниці листя; рослинний екстракт; матричні таблетки; иукровий діабет; інгібування альфа-глюкозидаз; хом'яки 


\section{Т. Е. Колиснык, Д. В. Лыткин, А. Л. Загайко, Е. А. Рубан Фармакологическая оценка матричных таблеток длительного высвобождения, содержащих сухой экстракт листьев черники, в качестве ингибитора альфа-глюкозидаз}

Листья черники обыкновенной являются источником природных полифенолов, которые улучшают гликемический контроль при диабетических состояниях благодаря различным механизмам, включая ингибирование кишечных $\alpha$-глюкозидаз. С целью повышения эффективности сухого экстракта листьев черники как средства, ингибирующего $\alpha$-глюкозидазы, были разработаны его матричные таблетки длительного высвобождения.

Целью данной работы была фармакологическая оценка сухого экстракта листьев черники и его матричных таблеток длительного высвобождения как средств, ингибирующих $\alpha$-глюкозидазы.

Материалы и методы. Матричные таблетки получали методом влажной грануляции. Экспериментальный алиментарный метаболический синдром с устойчивой инсулинорезистентностью индуцировали у сирийских хомяков диетой, богатой жирами и углеводами (HPFS) в течение 12 недель. С десятой недели диеты хомяки с модельной патологией получали сухой экстракт листьев черники, его матричные таблетки длительного высвобождения и таблетки воглибозы в качестве референтного препарата. В конце периода лечения проводили пероральный тест мальтозной нагрузки с определением динамики концентраций глюкозы в крови и инсулина в сыворотке крови.

Результаты и их обсуждение. По всем исследованным в данной работе показателям эффективность матричных таблеток, содержащих сухой экстракт листьев черники, превышала эффективность чистого экстракта и статистически значимо не отличалась от референтного препарата.

Выводы. Сухой экстракт листьев черники и его матричные таблетки оказывают антидиабетическое действие через несколько механизмов, включая не только ингибирование кишечных $\alpha$-глюкозидаз; следовательно, они могут рассматриваться как перспективные средства для лечения диабета и метаболического синдрома.

Ключевые слова: черники листья; растительный экстракт; матричные таблетки; сахарный диабет; ингибирование альфа-глюкозидаз; хомяки

\section{INTRODUCTION}

Diabetes mellitus type 2 (DMT2) is a chronic metabolic disorder that has spread worldwide, regardless of geographical location, population features and economic development level. According to the International Diabetes Federation (IDF) in 2017 the number of people with diabetes (20-79 years) was estimated to be 424.9 million and approximately $90 \%$ of them have type 2 diabetes. It should also be noted that in 2017 there were around 4 million cases of death caused by diabetes [1].

The current approaches in DMT2 therapy include modification of lifestyle, obesity treatment and administration of oral hypoglycemic agents like biguanides, sulfonylureas, thiazolidinediones, alpha-glucosidase inhibitors, dipeptidyl peptidase-4 inhibitors, etc. However, despite such an abundance of antidiabetic medications the global situation with diabetes has not been improved so far. Since these drugs should be administered during very long periods they have increased risk to develop serious adverse effects, which often restrict the effectiveness of glycemic control in diabetes. In this context, various substances and compounds of plant origin have been investigated in the treatment of diabetes experimental models and nowadays many of them are considered as a good alternative to synthetic antidiabetic drugs [2-4].

Bilberry (Vaccinium myrtillus L.) leaves are one of the richest sources of natural polyphenolic compounds. Among them hydroxycinnamic acids, especially chlorogenic acid, are the most dominant [5]. These phytochemicals possess antidiabetic action and improve glycemic control through several mechanisms, including inhibition of carbohydrate digestion and glucose absorption in the small intestine, stimulation of insulin secretion by pancreatic cells, as well as activation of insulin receptors and glucose uptake in the insulin-sensitive tissues [6-8]. However, natural polyphenols are known to have a low bioavailability and in the case of chlorogenic acid it is obviously related to its high absorption starting already in the stomach and followed by intensive metabolism in tissue cells and rapid elimination from the body $[9,10]$. Based on these considerations the formulation of sustained release matrix tablets containing $V$. myrtillus leaf dry extract has been developed. Taking into account the scientific evidence on $\alpha$-glucosidase inhibitory activity of $V$. myrtillus leaf extracts and its phytochemical constituents $[11,12]$, we believe that matrix tablet formulation will contribute to the increasing release of the polyphenolic substances directly in the small intestine and thus improving the effectiveness of the hypoglycemic treatment.

The aim is to study the pharmacological evaluation of sustained release matrix tablets containing V. myrtillus leaf dry extract as an $\alpha$-glucosidase inhibitory drug.

\section{MATERIALS AND METHODS}

Materials. Vaccinium myrtillus leaf dry extract (VMLDE) was obtained according to the method developed under the supervision of Dr. O. Koshoviy (Department of Pharmacognosy, National University of Pharmacy, Kharkiv, Ukraine) [13]. The excipients used to manufacture sustained release matrix tablets were hypromellose (HPMC) of grades Methocel K4M and Methocel K100LV (Dow Chemical Company, USA), Eudragit L100 (Evonik, Germany), microcrystalline cellulose (MCC) of a grade Avicel PH101 (FMC BioPolymer, USA), Plasdone S-630 (Ashland Inc., USA) and magnesium stearate (S.D. Fine. Chemicals Ltd., India). The tablets containing $0.2 \mathrm{mg}$ of voglibose ("Voksid" 
produced by Kusum Pharm LLC, Ukraine), a marketed $\alpha$-glucose inhibitor, were used as a reference drug in this study.

Preparation of sustained release matrix tablets. Matrix tablets were prepared by the wet granulation method. The composition of sustained release matrix tablets is given in Tab. 1. The tests of physical properties for manufactured matrix tablets including crushing strength, friability, weight variation, and assay were performed according to the State Pharmacopoeia of Ukraine [14].

Experimental animals. Fifty male 6-week-old Syrian hamsters (Mesocricetus auratus) weighting 70-90 g were used for this study. Animals were kept in the vivarium of the Central Research Laboratory, National University of Pharmacy (Kharkiv, Ukraine), according to the Guide for the Care and Use of Laboratory Animals of the National Research Council [15]. All experiments were conducted in accordance with the European Community Council Directive of 24 November 1986 (86/609/EEC) [16].

Induction of metabolic syndrome and experimental design. Experimental alimentary metabolic syndrome with persistent insulin resistance in hamsters was induced by highly palatable fat- and sugar-rich (HPFS) diet for 12 weeks [17]. Animals received about 29 grams of fat and 33 grams of carbohydrates per 100 grams of diet, while the energy value of fat was $40.3 \%$. In addition, each animal consumed in the diet at least one gram of free fructose per $100 \mathrm{~g}$ of body weight (b.w.) per day, which not only contributed to the disruption of glucose utilization, but also caused voluntary hyperphagia $[18,19]$. Animals of the intact control group were kept for 12 weeks on a standard balanced diet for hamsters.

Before the experiment all animals were divided into five groups $(n=10)$. Group I included intact control (IC) hamsters that were fed with standard balanced diet. Group II included pathology control (PC) animals fed with HPFS diet. Groups III and IV included metabolic syndrome hamsters treated with VMLDE (30 mg/kg b.w.) and sustained release matrix tablets $(71 \mathrm{mg} / \mathrm{kg}$ b.w. which corresponds

Table 1

\section{COMPOSITION OF SUSTAINED RELEASE MATRIX TABLETS}

\begin{tabular}{|l|c|}
\hline \multicolumn{1}{|c|}{ Name of ingredient } & Amount, mg per tablet \\
\hline \multicolumn{2}{|c|}{ Intragranular preparation } \\
\hline VMLDE & 275.0 \\
\hline Eudragit L100 & 162.5 \\
\hline HPMC K4M & 26.0 \\
\hline HPMC K100LV & 26.0 \\
\hline MCC & 128.0 \\
\hline \multicolumn{2}{|c|}{ Granulating solution } \\
\hline Plasdone S-630 \\
\hline Purified water \\
\hline \multicolumn{2}{|c|}{ q.s. } \\
\hline Magnesium stearate & 6.5 \\
\hline Total weight & $\mathbf{6 5 0 . 0}$ \\
\hline
\end{tabular}

to $30 \mathrm{mg} / \mathrm{kg}$ b.w. of VMLDE), respectively. Group V included metabolic syndrome hamsters treated with reference drug ( $20 \mathrm{mg} / \mathrm{kg}$ b.w. of voglibose). Animal equivalent doses were calculated based on the average daily therapeutic doses for humans and interspecies difference in mass and body surface area [20]. The treatment with the test and reference agents was started from the 10-th week of the diet and lasted for 14 days. The treating agents were given to the animals once a day through a gastric tube by dispersing them with $1 \mathrm{ml}$ of purified water. Animals of IC and PC groups received $1 \mathrm{ml}$ of distilled water in order to reproduce equal experimental conditions instead of treating agents. After the start of treatment, the diet of all experimental groups remained unchanged.

At the end of the 12-th week of the experiment the animals were deprived of free access to food for 8 hours, after that the biochemical tests were carried out. The treating agents were administered for the last time at 1 hour before biochemical testing.

Biochemical tests. Control of blood glucose was evaluated by an oral maltose loading test. One hour after the last treatment the animals were orally administered of $50 \%$ maltose solution at a dose of $3 \mathrm{~g} / \mathrm{kg}$. The sampling of blood was conducted immediately before maltose administration and 30, 60, 90, 120 min after loading maltose. The blood samples were collected from sublingual veins of hamsters. Glucose concentration levels in blood samples were measured by a One-Touch Ultra Easy ${ }^{\circledR}$ glucometer (LifeScan, USA) using One-Touch Ultra ${ }^{\circledR}$ test-stripes (LifeScan, USA). Serum insulin levels were measured by an enzyme-linked immunosorbent assay (ELISA) kit (DRG Instruments $\mathrm{GmbH}$, Germany) using a microstrip reader Stat Fax 303 plus (Awareness Technology, USA).

Glucose and insulin levels determined in the blood before maltose administration reflected the level of glycaemia on an empty stomach after two weeks of the treatment. The experimental data obtained before maltose loading were also used to calculate a homeostatic model assessment-insulin resistance (HOMA-IR) index. Inhibition of disaccharide digestion and absorption was assessed based on postprandial glucose and insulin levels calculated as areas under the corresponding concentrationtime curves by a trapezoid method.

Statistical analysis. Statistical analysis was carried out by variation-statistical method using non-parametric analysis (Mann-Whitney U-Test) with Statistica 7.0 and Microsoft Excel 2007 software. Results are presented as mean value \pm S.D. Significant levels were defined at $p \leq 0.05$.

\section{RESULTS AND DISCUSSION}

HPFS diet-induced metabolic syndrome resulted in persistent insulin resistance and glucose tolerance observed in all pathological animals. Intact control animals had insulin and glucose blood levels within physiological and age appropriate normal range.

Determination of HOMA-IR indices before maltose loading on an empty stomach allowed to overall assess 


\section{INSULIN RESISTANCE MARKERS IN BLOOD SERUM OF MALE SYRIAN HAMSTERS WITH INDUCED METABOLIC SYNDROME (DETERMINED ON AN EMPTY STOMACH)}

\begin{tabular}{|c|c|c|c|}
\hline Experimental group* & Glucose, mmol/L & Insulin, pmol/L & HOMA-IR \\
\hline IC & $5.49 \pm 0.32$ & $84.35 \pm 6.52$ & $1.85 \pm 0.16$ \\
\hline $\mathrm{PC}$ & $13.24 \pm 0.65^{* *}$ & $179.87 \pm 14.55^{* *}$ & $5.21 \pm 0.58^{* *}$ \\
\hline VMLDE matrix tablets & $7.90 \pm 0.37^{* *} / * * *$ & $122.64 \pm 10.31^{* *} / * * *$ & $2.96 \pm 0.26^{* *} / * * *$ \\
\hline Reference drug & $8.23 \pm 0.58^{* *} / * * *$ & $120.58 \pm 12.36^{* *} / * * *$ & $2.95 \pm 0.23^{* *} / * * *$ \\
\hline
\end{tabular}

Notes: ${ }^{*}-\mathrm{n}=10$ per group; values are expressed as mean \pm S.D.; ${ }^{* *}-\mathrm{p}<0.05$ compared with intact control animals;

*** $-\mathrm{p}<0.05$ compared with positive control animals.

the effectiveness of treating agents as antidiabetic drugs. It was revealed that all tested agents affected metabolic syndrome, however, none of them normalized biochemical markers to intact values (Tab. 2). Intragastric administration of VMLDE at a dose of $30 \mathrm{mg} / \mathrm{kg}$ for 14 days decreased blood glucose and immunoreactive insulin levels by 33.4 and $27.0 \%$, respectively; HOMA-IR index was accordingly decreased by $37.2 \%$. The matrix tablets of the same dose of VMLDE showed a slightly better result than pure VMLDE: the reduction of blood glucose levels in this group was observed to be $40.3 \%$ (which was the most among all tested agents), and the reduction of serum insulin was $31.8 \%$; the total change in these parameters led to a decrease of HOMA-IR by $43.2 \%$, which statistically significantly did not differ from the reference drug. The intragastric administration of voglibose tablets for two weeks resulted in blood glucose and serum insulin level reduction of $37.8 \%$ and $33.0 \%$, respectively, that decreased HOMA-IR index by $43.4 \%$ compared to the pathology control group.

An in-depth study of the mechanism of action for VMLDE and its matrix tablets included the performance

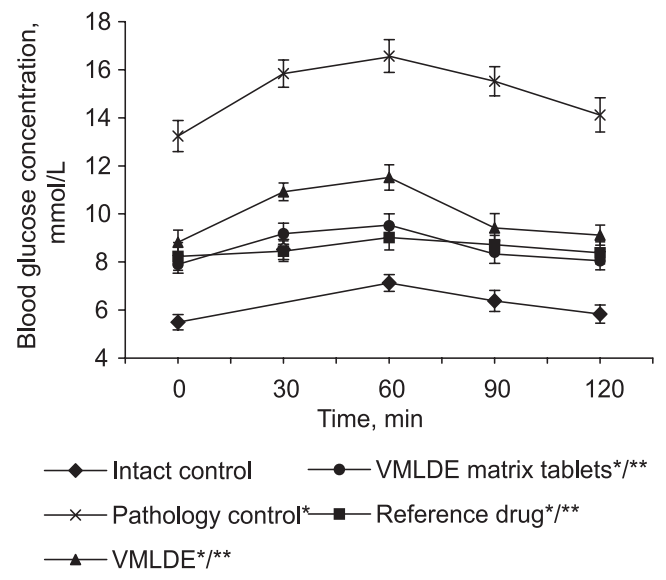

Fig. 1. The dynamics of glucose concentration ( $\mathrm{mmol} / \mathrm{L}$ ) in blood of hamsters with induced metabolic syndrome during 120 min after oral maltose load. Values are mean \pm S.D. with $n=10$

* $-\mathrm{p} \leq 0.05$ compared with intact control animals;

** $-\mathrm{p} \leq 0.05$ compared with pathology control animals of the maltose loading test. Since maltose is a disaccharide consisting of two glucose molecules, the dynamics of blood glucose and serum insulin levels during 2 hours after oral administration of maltose can be used to evaluate the effectiveness of intestinal $\alpha$-glucosidase inhibition.

Fig. 1 and 2 show the dynamics of blood glucose and serum insulin concentrations, respectively, after oral maltose load to hamsters. As it can be seen, in the intact control animals the blood glucose level increased from $5.49 \pm 0.32$ to $8.52 \pm 0.42 \mathrm{mmol} / \mathrm{L}$ at $30 \mathrm{~min}$ after maltose load; as a response to that, the insulin secretion also increased and resulted in serum insulin value of $208.42 \pm 12.22 \mathrm{pmol} / \mathrm{L}$ at this time point. Then blood glucose and serum insulin levels declined and after 2 hours became very close to baseline values registered on an empty stomach $(5.83 \pm 0.38 \mathrm{mmol} / \mathrm{L}$ and $88.34 \pm 6.42 \mathrm{pmol} / \mathrm{L}$, respectively).

For pathology control hamsters with diet induced metabolic syndrome the curves of glucose and insulin dynamics demonstrated all signs of persistent insulin resistance and impaired glucose tolerance. In that way, despite insulin and glucose levels were already elevated on an empty stomach they continued to rise after maltose

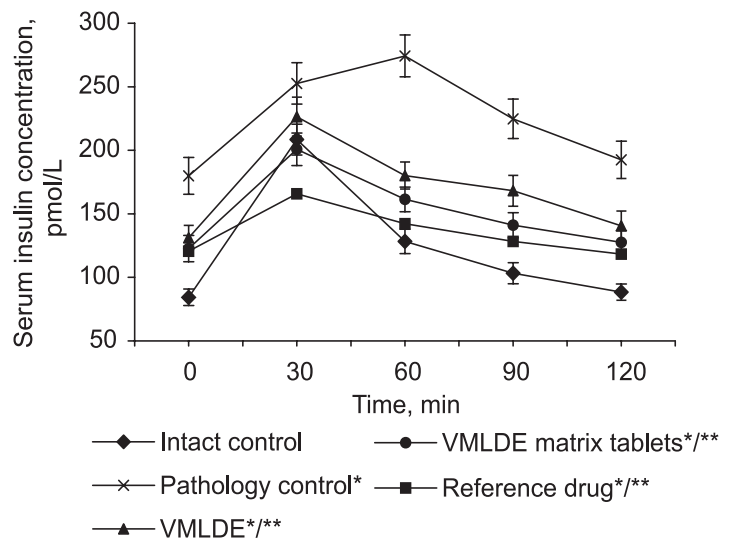

Fig. 2. The dynamics of insulin concentration (pmol/L) in blood serum of hamsters with induced metabolic syndrome during 120 min after oral maltose load. Values are mean \pm S.D. with $n=10$

$*_{-}$p $\leq 0.05$ compared with intact control animals;

**_ $\mathrm{p} \leq 0.05$ compared with pathology control animals 


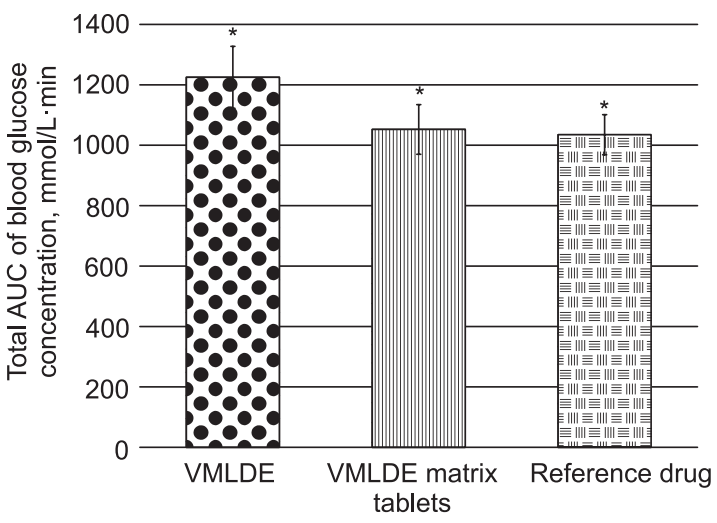

Fig. 3. Total AUC of blood glucose concentration versus time, $\mathrm{mmol} / \mathrm{L} \cdot \mathrm{min}$

$*_{-}$p $\leq 0.05$ compared with reference drug group animals

load. At 30 min after maltose administration, serum insulin level raised up to $252.65 \pm 16.23 \mathrm{pmol} / \mathrm{L}$, however, that did not accompany by reduction of blood glucose level which value was $15.84 \pm 0.57 \mathrm{mmol} / \mathrm{L}$. At $60 \mathrm{~min}$ glucose and insulin levels reached their maximum values of $16.57 \pm 0.68 \mathrm{mmol} / \mathrm{L}$ and $274.26 \pm 16.50 \mathrm{pmol} / \mathrm{L}$, respectively. After then both concentrations gradually decreased and at the end of the test became $14.12 \pm 0.71 \mathrm{mmol} / \mathrm{L}$ for glucose and $192.46 \pm 14.71 \mathrm{pmol} / \mathrm{L}$ for insulin.

In experimental group treated with pure VMLDE blood glucose level increased to $11.52 \pm 0.53 \mathrm{mmol} / \mathrm{L}$ at $60 \mathrm{~min}$ and then reduced to $9.42 \pm 0.59$ and $9.12 \pm 0.42 \mathrm{mmol} / \mathrm{L}$ at 90 and $120 \mathrm{~min}$, respectively. At the same time, the dynamics of serum insulin level showed a descending already after 30 min with average values of $226.48 \pm 15.39,180.12 \pm 10.62$, $168.18 \pm 12.17$ and $140.52 \pm 11.71 \mathrm{pmol} / \mathrm{L}$ at $30,60,90$ and $120 \mathrm{~min}$, respectively. Thus, the first $30 \mathrm{~min}$ of the test indicated that VMLDE possess a moderate $\alpha$-glucosidase inhibitory activity whilst total areas under both insulin and glucose concentration-time curves were significantly more as compared to the reference drug (Fig. 3, 4).

Animals received VMLDE matrix tablets demonstrated blood glucose and serum insulin levels that were significantly lower than in the group treated with pure VMLDE and close to the values of the reference group. That is, glucose concentration values were $9.18 \pm 0.44,9.51 \pm 0.49$, $8.41 \pm 0.47$ and $8.05 \pm 0.38 \mathrm{mmol} / \mathrm{L}$ while concentrations of serum insulin were $200.83 \pm 12.79,161.36 \pm 9.65$, $141.03 \pm 9.86$ and $127.62 \pm 9.18 \mathrm{pmol} / \mathrm{L}$ at $30,60,90$ and $120 \mathrm{~min}$, respectively (Fig. 1-2). However, as it is seen from the given values, the release of glucose into the blood was slightly more and consequently led to a slightly more secretion of insulin compared to positive control hamsters. The total areas under the concentration-time curves for this group were also slightly higher than for reference one, but there were no statistically significant differences between them (Fig. 3, 4).

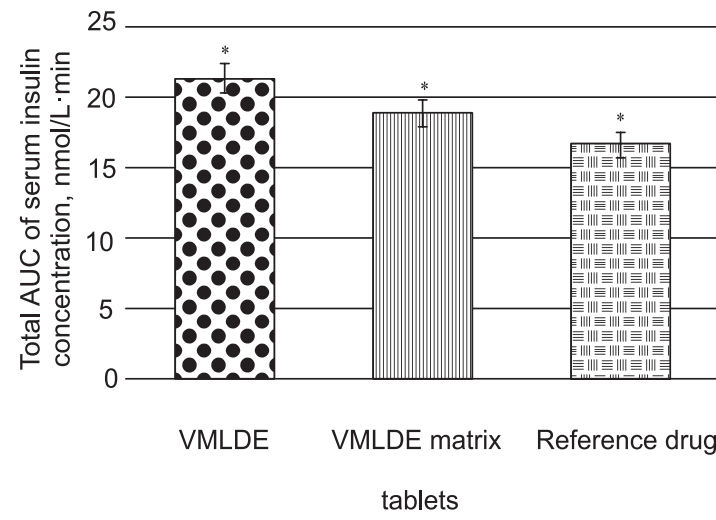

Fig. 4. Total AUC of serum insulin concentration versus time, $\mathrm{nmol} / \mathrm{L} \cdot \mathrm{min}$

$*_{\text {- }} \mathrm{p} \leq 0.05$ compared with reference drug group animals

The plot of concentration dynamics for blood glucose in the reference group treated with volglibose tablets is practically monotonous, whereas the plot of insulin concentration dynamics has only one small peak, immediately after the administration of maltose syrup (glucose concentration values were $8.45 \pm 0.43,9.02 \pm 0.52$, $8.72 \pm 0.39$ and $8.38 \pm 0.46 \mathrm{mmol} / \mathrm{L}$ and concentrations of serum insulin were $165.75 \pm 13.41,142.19 \pm 12.97$ $128.40 \pm 10.25$ and $118.28 \pm 11.57 \mathrm{pmol} / \mathrm{L}$ at $30,60,90$ and 120 min, respectively; Fig. 1, 2). This indicates a high efficiency of voglibose as an intestinal $\alpha$-glucosidase inhibitor. In addition, both total area under the curve indicators were the lowest for this group (Fig. 3, 4).

\section{CONCLUSIONS}

1. By all markers studied in this work the effectiveness of VMLDE matrix tablets in a hamster model of induced metabolic syndrome with persistent insulin resistance exceeded that one of pure extract. Thus, it can be concluded that developed matrix formulation has a positive impact on improving the bioavailability of the herbal extract phytoconstituents.

2. The effectiveness of VMLDE matrix tablets statistically significantly did not differ from reference drug "Voksid", which is currently registered in the Ukrainian market as an antidiabetic medication.

3. VMLDE and its matrix tablets demonstrated a moderate $\alpha$-glucosidase inhibitory activity, however the results of this study indicate that they possess the therapeutic action in metabolic syndrome and DMT2 treatment through several mechanisms (including, but not only intestinal $\alpha$-glucosidase inhibition). In this context, VMLPE and its matrix tablets can be considered as promising agents in DMT2 and metabolic syndrome treatment.

Conflict of Interests: authors have no conflict of interests to declare. 


\section{REFERENCES}

1. International Diabetes Federation, Diabetes Atlas, 8-th ed. - Brussels, Belgium : International Diabetes Federation, 2017. - Available at : http:// www.diabetesatlas.org/resources/2017-atlas.html

2. Tundis, R. Natural Products as $\alpha$-Amylase and $\alpha$-Glucosidase Inhibitors and their Hypoglycaemic Potential in the Treatment of Diabetes : An Update / R. Tundis, M. R. Loizzo, F. Menichini // Mini. Rev. Med. Chem. - 2010. - Vol. 10, Issue 4. - P. 315-331. doi: 10.2174/138955710791331007

3. Coman, C. Plants and Natural Compounds with Antidiabetic Action / C. Coman, O. D. Rugină, C. Socaciu // Not. Bot. Horti. Agrobo. - 2012. - Vol. 40, Issue 1. - 314 p. doi: 10.15835/nbha4017205

4. Polyphenols-rich natural products for treatment of diabetes / S. Dragan, F. Andrica, M. C. Serban, R. Timar // Curr. Med. Chem. - 2014. - Vol. 22, Issue 1. - P. 14-22. doi: 10.2174/0929867321666140826115422

5. Перспективи створення нового гіпоглікемічного лікарського засобу на основі біологічно активних речовин листя чорниці звичайної / I. О. Количев, О. М. Кошовий, А. Л. Загайко та ін. // Фармаком. - 2016. - № 1. - С. 67-73.

6. Roles of Chlorogenic Acid on Regulating Glucose and Lipids Metabolism: A Review / S. Meng, J. Cao, Q. Feng et al. // Evid. Based. Complement Alternat. Med. - 2013. - Vol. 2013. - P. 1-11. doi: 10.1155/2013/801457

7. Ong, K. W. Anti-diabetic and anti-lipidemic effects of chlorogenic acid are mediated by ampk activation / K. W. Ong, A. Hsu, B. K. Tan // Biochem. Pharmacol. - 2013. - Vol. 85, Issue 9. - P. 1341-1351. doi: 10.1016/j.bcp.2013.02.008

8. Рубан, Е. А. Перспективы создания противодиабетических препаратов на основе полифенолов : механизмы гипогликемического действия и фармакокинетика / Е. А. Рубан, Т. Е. Колиснык, Г. Д. Слипченко // Annals of Mechnikov Institute. - 2015. - № 4. - С. 17-24.

9. Chlorogenic acids from green coffee extract are highly bioavailable in humans / A. Farah, M. Monteiro, C. M. Donangelo, S. Lafay // J. Nutr. - 2008. Vol. 138, Issue 2. - P. 2309-2315. doi: 10.3945/jn.108.095554

10. Lafay, S. Bioavailability of phenolic acids / S. Lafay, A. Gil-Izquierdo // Phytochem. Rev. - 2007. - Vol. 7, Issue 2. - P. 301-311. doi: 10.1007/s11101-007-9077-x

11. Chemical Composition, Antioxidant and $\alpha$-Glucosidase-Inhibiting Activities of the Aqueous and Hydroethanolic Extracts of Vaccinium myrtillus Leaves / K. Bljajić, R. Petlevski, L. Vujić et al. // Molecules. - 2017. - Vol. 22, Issue 5. - 703 p. doi: 10.3390/molecules22050703

12. Caffeic and chlorogenic acids inhibit key enzymes linked to type 2 diabetes (in vitro) : a comparative study / G. Oboh, O. M. Agunloye, S. A. Adefegha et al. // J. Basic. Clin. Physiol. Pharmacol. - 2015. - Vol. 26, Issue 2. - P. 165-170. doi: 10.1515/jbcpp-2013-0141

13. Пат. 111134 Україна, МПК А 61 К 36/45, А 61 К 31/195, А 61 К 31/05, А 61 Р 3/10. Спосіб одержання лікувально-профілактичного засобу із гіпоглікемічною дією з листя чорниці звичайної / Кошовий О. М., Загайко А. Л., Количев І. О., Филимоненко В. П., Комісаренко А. М. Заявл.: 30.06.2015; опубл.: 25.03.2016. - Бюл. № 26.

14. Державна фармакопея України : в 3-х т. / Державне підприємство «Український науковий фармакопейний центр якості лікарських засобів». - 2-е вид. - Х. : Український науковий фармакопейний центр якості лікарських засобів, 2015. - Т. 1. - 1128 с.

15. Guide for the care and use of laboratory animals. - 8-th ed. - Washington : The National Academies Press, 2011. - 246 p.

16. European convention for the protection of vertebrate animals used for experimental and other scientific purpose. - Strasbourg: Council of Europe, 1986. - 52 p.

17. A Hamster Model of Diet-Induced Obesity for Preclinical Evaluation of Anti-Obesity, Anti-Diabetic and Lipid Modulating Agents / L. S. Dalbøge, P. J. Pedersen, G. Hansen et al. // PLoS One. - 2015. - Vol. 10, Issue 8. - e0135634 p. doi: 10.1371/journal.pone.0135634

18. High-fat and fructose intake induces insulin resistance, dyslipidemia, and liver steatosis and alters in vivo macrophage-to-feces reverse cholesterol transport in hamsters / F. Briand, Q. Thiéblemont, E. Muzotte, T. Sulpice // J. Nutr. - 2012. - Vol. 142, Issue 4. - P. 704-709. doi: 10.3945/jn.111.153197

19. Comparison between cafeteria and high-fat diets in the induction of metabolic dysfunction in mice / T. S. Higa, A. V. Spinola, M. H. Fonseca-Alaniz, F. S. Evangelista // Int. J. Physiol. Pathophysiol. Pharmacol. - 2014. - Vol. 6. - P. 47-54.

20. Nair, A. B. A simple practice guide for dose conversion between animals and human / A. B. Nair, S. A. Jacob // J. Basic. Clin. Pharm. - 2016. - Vol. 7 , Issue 2. - 27 p. doi: 10.4103/0976-0105.177703

\section{REFERENCES}

1. International Diabetes Federation. IDF Diabetes Atlas, $8^{\text {th }}$ ed. (2017). Brussels, Belgium: International Diabetes Federation. Available at: http:// www.diabetesatlas.org/resources/2017-atlas.htm

2. Tundis, R., Loizzo, M. R., Menichini, F. (2010). Natural Products as Amylase and Glucosidase Inhibitors and their Hypoglycaemic Potential in the Treatment of Diabetes: An Update. Mini-Reviews in Medicinal Chemistry, 10 (4), 315-331. doi: 10.2174/138955710791331007

3. Coman, C., Rugina, O. D., Socaciu, C. (2012). Plants and Natural Compounds with Antidiabetic Action. Notulae Botanicae Horti Agrobotanici ClujNapoca, 40 (1), 314. doi: 10.15835/nbha4017205

4. Dragan, S., Andrica, F., Serban, M.-C., Timar, R. (2014). Polyphenols-Rich Natural Products for Treatment of Diabetes. Current Medicinal Chemistry, 22 (1), 14-22. doi: 10.2174/0929867321666140826115422

5. Kolychev, I. O., Koshovyi, O. M., Zahaiko, A. L., Krasnikova, T. O., Kovalova, A. M. (2016). Farmakom, 1, 67-73.

6. Meng, S., Cao, J., Feng, Q., Peng, J., Hu, Y. (2013). Roles of Chlorogenic Acid on Regulating Glucose and Lipids Metabolism: A Review. Evidence-Based Complementary and Alternative Medicine, 2013, 1-11. doi: 10.1155/2013/801457

7. Ong, K. W., Hsu, A., Tan, B. K. H. (2013). Anti-diabetic and anti-lipidemic effects of chlorogenic acid are mediated by ampk activation. Biochemical Pharmacology, 85 (9), 1341-1351. doi: 10.1016/j.bcp.2013.02.008

8. Ruban, E. A., Kolisnyk, T. E., Slipchenko, G. D. (2015). Annals of Mechnikov Institute, 4, 17-24.

9. Farah, A., Monteiro, M., Donangelo, C. M., Lafay, S. (2008). Chlorogenic Acids from Green Coffee Extract are Highly Bioavailable in Humans. The Journal of Nutrition, 138 (12), 2309-2315. doi: 10.3945/jn.108.095554

10. Lafay, S., Gil-Izquierdo, A. (2007). Bioavailability of phenolic acids. Phytochemistry Reviews, 7 (2), 301-311. doi: 10.1007/s11101-007-9077-x

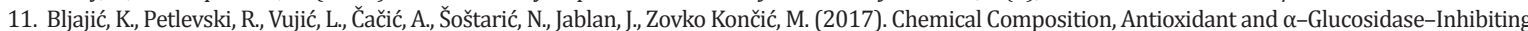
Activities of the Aqueous and Hydroethanolic Extracts of Vaccinium myrtillus Leaves. Molecules, 22 (5), 703. doi: 10.3390/molecules22050703

12. Oboh, G., Agunloye, O. M., Adefegha, S. A., Akinyemi, A. J., Ademiluyi, A. O. (2015). Caffeic and chlorogenic acids inhibit key enzymes linked to type 2 diabetes (in vitro): a comparative study. Journal of Basic and Clinical Physiology and Pharmacology, 26 (2). doi: 10.1515/jbcpp-2013-0141

13. Koshovyi, O. M., Zahaiko, A. L., Kolychev, I. O., Fylymonenko, V. P., Komisarenko, A. M. (2016). Sposib oderzhannia likuvalno-profilaktychnoho zasobu iz hipohlikemichnoiu diieiu z lystia chornytsi zvychainoi. Pat. 111134 Ukraine, MPK A61K 36/45, A61K 31/195, A61K 31/05, A61P 3/10; declared 30.06.2015, published 25.03.2016, № 26 .

14. Derzhavna Farmakopeia Ukrainy : v 3 tomakh. (2015). Kharkiv: Ukrainskyi naukovyi farmakopeinyi tsentr yakosti likarskykh zasobiv, $1,1128$.

15. Guide for the Care and Use of Laboratory Animals, 8-th edition. (2011). Washington: The National Academies Press, 246. doi: 10.17226/12910

16. European convention for the protection of vertebrate animals used for experimental and other scientific purposes. (1986). Strasbourg : Council of Europe, 52 .

17. Dalbøge, L. S., Pedersen, P. J., Hansen, G., Fabricius, K., Hansen, H. B., Jelsing, J., Vrang, N. (2015). A Hamster Model of Diet-Induced Obesity for Preclinical Evaluation of Anti-Obesity, Anti-Diabetic and Lipid Modulating Agents. PLOS ONE, 10 (8), e0135634. doi: 10.1371/journal.pone.0135634

18. Briand, F., Thiéblemont, Q., Muzotte, E., Sulpice, T. (2012). High-fat and fructose intake induces insulin resistance, dyslipidemia, and liver steatosis and alters in vivo macrophage-to-feces reverse cholesterol transport in hamsters. J Nutr, 142 (4), 704-709. doi: 10.3945/jn.111.153197

19. Higa, T. S., Spinola, A. V., Fonseca-Alaniz, M. H., Evangelista, F. S. (2014). Comparison between cafeteria and high-fat diets in the induction of metabolic dysfunction in mice. Int J Physiol Pathophysiol Pharmacol, 6 (1), 47-54.

20. Nair, A., Jacob, S. (2016). A simple practice guide for dose conversion between animals and human. Journal of Basic and Clinical Pharmacy, 7 (2) 27. doi: $10.4103 / 0976-0105.177703$ 
Information about authors:

Kolisnyk T., PhD student at the Department of Industrial Technology of Drugs, National University of Pharmacy.

E-mail: kolisnyktatyana@gmail.com. ORCID: https://orcid.org/0000-0002-2682-0360

Lytkin D., PhD student at the Department of Biological Chemistry, National University of Pharmacy. E-mail: d.v.lytkin@gmail.com. ORCID: https://orcid.org/0000-0002-4173-3046

Zagayko A., Doctor of Pharmacy, Professor, Vice-Rector for scientific and pedagogical work, National University of Pharmacy.

E-mail: zagayko@nuph.edu.ua. ORCID: https://orcid.org/0000-0002-2226-976X

Ruban O., Doctor of Pharmacy, Professor, Head of the Department of Industrial Technology of Drugs, National University of Pharmacy.

E-mail: ruban_elen@ukr.net. ORCID: http://orcid.org/0000-0002-2456-8210

Відомості про авторів:

Колісник Т. Є., аспірант кафедри заводської технології ліків, Національний фармацевтичний університет

E-mail: kolisnyktatyana@gmail.com. ORCID: https://orcid.org/0000-0002-2682-0360

Литкін Д. В., аспірант кафедри біологічної хімії, Національний фармацевтичний університет. E-mail: d.v.lytkin@gmail.com

ORCID: https://orcid.org/0000-0002-4173-3046

Загайко А. Л., д-р біол. наук, професор, проректор з науково-педагогічної роботи, Національний фармацевтичний університет.

E-mail: zagayko@nuph.edu.ua. ORCID: https://orcid.org/0000-0002-2226-976X

Рубан О. А., д-р фарм. наук, професор, завідувач кафедри заводської технології ліків, Національний фармацевтичний університет.

E-mail: ruban_elen@ukr.net. ORCID: http://orcid.org/0000-0002-2456-8210

Сведения об авторах:

Колиснык Т. Е., аспирант кафедры заводской технологии лекарств, Национальный фармацевтический университет

E-mail: kolisnyktatyana@gmail.com. ORCID: https://orcid.org/0000-0002-2682-0360

Лыткин Д. В., аспирант кафедры биологической химии, Национальный фармацевтический университет. E-mail: d.v.lytkin@gmail.com.

ORCID: https://orcid.org/0000-0002-4173-3046

Загайко А. Л., д-р биол. наук, профессор, проректор по научно-педагогической работе, Национальный фармацевтический университет. E-mail: zagayko@nuph.edu.ua. ORCID: https://orcid.org/0000-0002-2226-976X

Рубан Е. А., д-р фарм. наук, профессор, заведующая кафедрой заводской технологии лекарств, Национальный фармацевтический университет. E-mail: ruban_elen@ukr.net. ORCID: http://orcid.org/0000-0002-2456-8210

Рекомендована д. мед. н., професором С. Ю. Штриголем

Надійшла до редакції 11.05.2018 p. 